exceeding 200 feet (Ryder, J. P. 1964. A preliminary study of the breeding biology of the Ross' Goose. Wildf. Trust 15th Ann. Rep.). This note describes the importance of one of these "Arctic hills" to some of the breeding birds of this area in 1965 .

While traveling down the Perry River on July 14, 1965, J. Ryder, Sam Emingak, a Kogmiut Eskimo, and myself stopped to check the eyrie of a Peregrine Falcon (Falco peregrinus) on the side of an outcropping on the southeastern side of Lee Island $\left(67^{\circ}\right.$ $\left.36^{\prime} \mathrm{N}, 102^{\circ} 5^{\prime} \mathrm{W}\right)$. The eyrie, found to be active, was inaccessible at this time. While looking for a way to approach the eyrie, we found a female Canada Goose (Branta canadensis) incubating four eggs in an abandoned nest of a Rough-legged Hawk (Buteo lagopus) about 40 feet above the rocks. The nest was less than 15 feet from the falcon eyrie. A short while later on the summit of the same hill, we found a nest of the American Pipit (Anthus spinoletta) containing four newly-hatched young and one egg, in the grass amid rocks. Meanwhile, a pair of Rough-legged Hawks was vociferously defending a territory that appeared to be the same hill; however, the nest was not found on this date.

On July 25 the Rough-legged Hawk nest containing three young about three weeks old was found on the south end of this hill about 300 yards from the Peregrine Falcon eyrie. The Canada Goose nest was found destroyed at this time, but information regarding time or cause of failure is lacking. The falcon eyrie, reached July 31 by means of ropes, contained one young and one egg containing a dead embryo.

Thus, four species representing three families nested on the same outcropping within 300 yards of each other. Interspecific aggression among the breeding birds was not observed; it is not known if the goose nesting failure was due to the raptors. The other three nests were successful up to the time we left. Lapland Longspur
(Calcarius lapponicus) and Horned Lark (Eremophila alpestris) were common in the area and in one instance the former was taken by the Rough-legged Hawks for food for their young.

\section{BIRDS FEEDING AT SAPSUCKER TREES}

by Robert W. Nero, Regina

Records of several species of insects and birds feeding at holes drilled in trees by the Yellow-bellied Sapsucker were recently reported by Walter $P$. Nickell (1965. Birds and insects feed at sapsucker trees. Bird-Banding, 36: 192-193). These were summer observations of the following birds: Rubythroated Hummingbird (for which this habit is well known, as pointed out by Nickell - and see Blue Jay, $23: 80-81$ ), Hairy Woodpecker, Downy Woodpecker, Black-and-white Warbler, Black-throated Green Warbler, and Baltimore Oriole.

This fall I observed four additional warbler species drinking sap at a sapsucker tree. A migrant immature Yellow-bellied Sapsucker drilled holes in a mature Chinese Elm (Ulmus pumila) in our yard, for the first time, on September 22, 1965. Late that evening I watched a tardy Myrtle Warbler and a Palm Warbler feeding on sap at the newly opened holes. The sapsucker remained for a few days, opening new holes daily in the main trunk of the tree from about one to three feet above the ground. On the evening of September 26, I saw a Myrtle Warbler again, plus an Orange-crowned Warbler and a Blackpoll Warbler, visiting the sapsucker tree. On these unseasonably cold and windy days the warblers, their plumage all awry, clung with difficulty to the bare tree trunk while drinking from the holes, and it looked as if they were drawing upon a familiar emergency food source. Sapsucker trees may provide an important supplementary food supply for a variety of fall migrants, as well as for summer breeding ground associates. 